\title{
GROWTH, CANE YIELD AND SUGAR CONTENT OF SIX GENOTYPES OF SUGARCANE IN A FOREST ZONE OF SOUTHEASTERN NIGERIA
}

\author{
D. A. Okpara and P.I. Okocha \\ College of Crop and Soil Sciences \\ Michael Okpara University of Agriculture. Umudike
}

\begin{abstract}
The growth and yield of six sugarcane genotypes were studied in field plots between 1999 and 2001, at Umudike, in the humid forest zone of southeastern Nigeria. Treatments comprised five improved sugarcane genotypes (NCS 001, NCS 003, NCS 004, NCS 005 and C062175) and one local variety (Umudike Local) arranged in a randomized complete block design (RCBD) with three replications. Cultivar NCS 003 gave significantly the highest stalk lengths and cane yields in both the plant-cane and ratoon crops. The genotype NCS 005 , on the other hand, gave the highest cane yield in the plant-cane but not in the ratoon crop, while C062175 gave the least yield in the plant-cane but had one of the highest yields in the ratoon crop. Sugar concentration (Brix \%) was highest in Umudike Local in the plant-cane crop.
\end{abstract}

Key words: Sugarcane, genotypes, growth. cane yield. sugar content.

\section{INTRODUCTION}

Sugarcane (Saccharum officinarum L.), a member of the Poaceae family, originated in New Guinea (Brandes, 1956) and is an important cultivated crop in the inland valleys of Nigeria (Busari et al., 1997). While industrial cane is grown mainly in sugar estates and processed into sugar, the chewing cane is grown by traditional farmers and normally chewed raw for its sweet refreshing juice. Although domestic sugar industries only produce about five percent of the national sugar requirements, very little proportion of the chewing cane is processed into sugar (Busari et al., 1997).

Commercial sugarcane production in Nigeria has been concentrated in the north of the country, where sugar estates and industries exist. Consequently, there are more research information on sugarcane production in the northern states (Kwon-Ndung, 1998; Ishaq et al., 1998; Ndarubu et al., 1998). Despite the lack of information on sugarcane production in the eastern states of Nigeria, farmers grow sugarcane on small farm holdings in the region. Research information is therefore necessary for advising the farmers, because sugarcane production is currently being encouraged nationwide. through the Nationally Coordinated Research Projects (NCRP).

Research into the diversity of morphological characteristics and yield of different genotypes of any crop has generally been recognized as fundamental for improvement programme of the crop. Alexander (1987) noted that development and selection of the right varieties have contributed 30 percent to increased sugar yield and biomass production while improved agronomic practices have contributed 70 percent. The objective of this study is, therefore, to evaluate and select promising sugarcane genotypes, based on growth and yield performance at Umudike, in the humid forest zone of southeastern Nigeria.

\section{MATERIALS AND METHODS}

Two field studies were carried out between 1999 and 2001 at the inland valley swamp of Michael Okpara University of Agriculture Research Farm, Umudike (Longitude $07^{\circ} 33^{\mathrm{l}} \mathrm{E}$, Latitude $05^{\mathrm{O}} 29^{1} \mathrm{~N}$, Aititude $122 \mathrm{~m}$ ). Composite soil samples were collected from the experimental site at $0-15 \mathrm{~cm}$ depths for analysis. Rainlall data were collected from the National Root Crops Research Institute (NRCRI) agrometeorological station, which is located a few metres from the experimental site.

The experiment was conducted as a randomized complete block design (RCBD) with three replications. Treatments comprised five improved sugarcane genorypes (NCS 001, NCS 003, NCS 004, NCS 005 and $\mathrm{C} 062175$ ) obtained from National Cereals Research Institute (NCRI), Badeggi, and one local variety (Umudike Local). Each plot ( $4 \mathrm{~m} \times 4 \mathrm{~m})$ had four 1 metre ridges. Three - bud - cane setts of each genotype were laid end-to-end on the base of grooves created on the crest of the ridges and covered with soil on $17^{\text {th }}$ September, 1999. There were 9 setts of each genotype per ridge. These setts were obtained from seven months old plants established earlier in the year for the purpose of generating planting materials.

Fertilizer was applied at the rate of $100 \mathrm{kgN} / \mathrm{ha}$ as urea, $60 \mathrm{kgP}_{2} \mathrm{O}_{5} / \mathrm{ha}$ as single super phosphate and 5 
$90 \mathrm{kgK}_{2} \mathrm{O}$ as muriate of potash at 2 months after planting (MAP). Earthening up of the canes was done with hoe at 5 MAP while hoe weeding was done thrice at 2,5 and 8 MAP.

Measurements and yield data were based on the two middle rows in each plot. The plant-cane crop was harvested at 10 MAP on $4^{\text {th }} \mathrm{July,} 2000$ while the first-ratoon crop was harvested 8 months after harvest of the plant-cane crop on $5^{\text {th }}$ March, 2001. Records were made on the number of stalks, number of leaves, number of internodes/stalk, number of millable stalks/ $\mathrm{m}^{2}$, stalk length $(\mathrm{cm})$ and girth $(\mathrm{cm})$. Plant height was obtained by measuring the distance from the ground to the top visible dewlap and getting the average, while girth was measured using venier calipers. At each harvest, the middle two rows of each plot were cut and fresh weight obtained. Sugar concentration (\% Brix) in the stalk was estimated using a field refractometer. Brix reading was recorded after dropping the juice of each genotype on the refractometer.

Data were subjected to Analysis of variance according to the procedures for a randomized complete block design as outlined by Little and Hills (1978). Significant treatment means were separated using the Duncan's New Multiple Range Test (DNMRT).

Table 1: Soil physical and chemical characteristics of the experimental site

\begin{tabular}{ll}
\hline Physical characteristics & \\
Sand $(\%)$ & 60.1 \\
Clay $(\%)$ & 25.1 \\
Silt $(\%)$ & 14.8 \\
Textural class & Sandy clay loam \\
Chemical characteristics & \\
OM $(\%)$ & 1.82 \\
$\mathrm{~N}(\%)$ & 0.11 \\
Avail. $\mathrm{P}\left(\mathrm{mgkg}^{-1}\right)$ & 19.0 \\
Exch. K(Cinol kg & $-1)$ \\
pH $\left(\mathrm{H}_{2} \mathrm{O}\right)$ & 0.11 \\
\hline
\end{tabular}

\section{RESULTS AND DISCUSSION}

The soil of the experimental site was a sandy clay loam with low $\mathrm{pH}$ and high potassium and phosphorus but low nitrogen contents (Table 1). Rainfall was generally high during the cropping season of April to October but very low during the dry months of November to February (Table 2). Annual rainfall was adequate in 2000 $(1669.5 \mathrm{~mm})$ but high in $1999(2701.3 \mathrm{~mm})$ and 2001 $(2189.8 \mathrm{~mm})$. Sugarcane needs $1500-1800 \mathrm{~mm}$ rain (Rehm and Espig, 1991). The minimum and maximum temperatures fell mostly within the range of $21^{\circ} \mathrm{C}-$ $35^{\circ} \mathrm{C}$ recommended by Onwueme and Sinha (1991) for sugarcane.

Cane genotype NCS 001 produced signifi- cantly the least number of leaves but the highest number of internodes while Umudike Local gave the highest number of leaves but the least number of internodes in the ratoon crop (Table 3). The NCS 003 genotype produced significantly the longest stalks while C062175 and NCS 005 gave the shortest stalks in the plant-cane and ratoon crops, respectively. Earlier workers (Boerma, 1979; Ugbaja el al., 1994: Okpara and Ibiam, 2000; Tanimu et al., 2000) have reported variations in plant height among cultivars of various crops. Cane stalk girth was significantly higher in NCS 005 than in others which were similar. In general, higher values for number of leaves, number of internodes and stalk height were obtained in the ratoon than the plant-cane crop in most genotypes.

Sugar concentration in the genotypes varied significantly in the plant-cane crop, with Umudike Local producing the highest brix of 28.3 percent while the lowest value of 21.7 percent occurred in C062175, which did not differ from the other genotypes (Table 4). The number of millable stalks $/ \mathrm{m}^{2}$ in the ratoon crop was significantly highest in NCS 003 and C062175 but least in NCSOOL, which was statistically similas to the other genolypes.

Cane yields ranged from 21.2 tha in $\mathrm{C} 062175$ to $71.0 \mathrm{t} / \mathrm{ha}$ in NCS 005 with a mean of $51.7 \mathrm{t} / \mathrm{ha}$ in the plant-cane crop and 13.9t/ha in NCS 001 to 38.6 tha in NCS 003 with a mean of $25.3 t /$ ha in the ratoon crop (Table 4). In the plant-cane crop. NCS 005, NCS 003. NCS 001 and Umudike Local had statistically similar yield values which were significantly higher than the yield of $\mathrm{CO} 62175$. In the ratoon crop, however, NCS 003 and 0062175 had statistically similar cane yield values which were markedly higher than the yields in other genotypes. NCS 005 and C062175 genotypes exhibited differential cane yield responses in the plantcane and ratoon crops. For example, NCS 005 gave the highest cane yield (71.0t/ha) in the plant-cane crop but had one of the least yields (20.6t/ha) in the ratoon crop. C062175 genotype gave the least yield $(21.2 \mathrm{t} / \mathrm{ha})$ in the plant cane crop but was a top yielder $(37.94 / \mathrm{ha}$ ) in the ratoon crop. Except for C062175, yields were much lower in the ratoon than in the plant-cane crop. Glaz et al., (1989) had reported that yield of cane usually declines from the plant-cane through the second ratoon crop. The highest yields of 69.3 and $71.0 t /$ ha obtained for NCS 003 and NCSOO5 genotypes, respec tively, in the plant-cane crop were satisfactory when compared with the yield of 73.1t/ha obtained by Agboire and Ishaq (1999) for the NCS 003 (BD 95-030) genotype in the southern guinea savanna of Nigeria.

Correlation analysis showed that stalk length was positively and significantly correlated with cane yield in the plant-cane crop while number of millable stalks was positively and highly significantly correlated with cane yield in the ratoon crop (Table 5). Cerrizuela 
Table 2: Weather records during the period of the experiment

\begin{tabular}{|c|c|c|c|c|c|c|c|c|c|}
\hline \multirow[b]{2}{*}{ Month } & \multicolumn{3}{|c|}{ Rainfall (mm) } & \multicolumn{3}{|c|}{ Minimum Temp. $\left({ }^{\circ} \mathrm{C}\right)$} & \multicolumn{3}{|c|}{ Maximum Temp $\left({ }^{\circ} \mathrm{C}\right)$} \\
\hline & 1999 & 2000 & $200 !$ & 1999 & 2000 & 20001 & 1999 & 2000 & 2001 \\
\hline $\operatorname{Ian}$ & 45.6 & 4.8 & 0.0 & 21 & 23 & 20 & 32 & 33 & 33 \\
\hline Feb & 98.1 & 0.9 & 7.6 & 24 & 22 & 22 & 36 & 34 & 35 \\
\hline Mar & 203.4 & 13.6 & 175.9 & 24 & 23 & 23 & 35 & 35 & 34 \\
\hline April. & 192.0 & 164.5 & 224.1 & 25 & 24 & 23 & 34 & 33 & 32 \\
\hline May & 319.9 & 153.6 & 194.3 & 24 & 24 & 23 & 33 & 32 & 32 \\
\hline June & 296.6 & 265.2 & 522.5 & 23 & 23 & 23 & 31 & 31 & 30 \\
\hline July & 284.4 & 265.2 & 273.5 & 23 & 23 & 22 & 30 & 30 & 29 \\
\hline Aug. & 382.2 & 216.1 & 179.0 & 23 & 24 & 22 & 29 & 30 & 28 \\
\hline Sept. & 395.3 & 277.5 & 317.2 & 23 & $2 A$ & 22 & 29 & 30 & 29 \\
\hline Oct. & 433.7 & 228.4 & 277.1 & 23 & 24 & 23 & 30 & 31 & 30 \\
\hline Nov. & 50.1 & 759 & 18.6 & 23 & 24 & 23 & 32 & 32 & 32 \\
\hline Dec. & 0.0 & 3.8 & 0.0 & 22 & 21 & 22 & 31 & 32 & 32 \\
\hline Total & 27013 & 1660.5 & 2189.8 & & & & & & \\
\hline
\end{tabular}

Table 3: Crop growth characteristics of six sugar cane genotypes (1999-2001)

\begin{tabular}{|c|c|c|c|c|c|c|c|c|}
\hline \multirow[b]{2}{*}{ Variety } & \multicolumn{2}{|c|}{ Number of leaves/stalk } & \multicolumn{2}{|c|}{$\begin{array}{l}\text { Number of } \\
\text { intemodes/stalk }\end{array}$} & \multicolumn{2}{|c|}{ Stalk length $(\mathrm{cm})$} & \multicolumn{2}{|c|}{ Stalk ginh $(\mathrm{cm})$} \\
\hline & Plant-cane & Ratoon & Plant-cane & Ratoon & Plant-cane & Ratoon & Plant-cane & Ratoon \\
\hline NCS 001 & 10.3 & $10,2^{6}$ & 18.2 & $29.5^{3}$ & $200.3^{\text {ibcat }}$ & $217.3^{4}$ & $4.3^{b}$ & 3.5 \\
\hline NCS 003 & 100 & $18.7^{\mathrm{b}}$ & 210 & $25.7^{312}$ & $254.3^{\mathrm{n}}$ & $261.7^{\mathrm{a}}$ & $3.7^{6}$ & 3.3 \\
\hline NCSOOA & 97 & $103^{\circ}$ & 193 & $27.5^{\text {ab }}$ & $183.7^{\mathrm{ci}}$ & $202.0^{\mathrm{hnt}}$ & $3.7^{\mathrm{b}}$ & 3.7 \\
\hline NCS 005 & 92 & $13.5^{\mathrm{th}}$ & 21.2 & $22.0^{6 t}$ & $197.7^{\text {bet }}$ & $174.2^{\mathrm{e}}$ & $5.3^{\mathrm{a}}$ & 4.1 \\
\hline 0062175 & 9.2 & $11.3^{6 x}$ & 22.0 & $26.0^{\text {tis }}$ & $146.3^{\circ}$ & $186.5^{3 x}$ & $4.3^{b}$ & 4.2 \\
\hline Umudike local & 92 & $22.2^{\sharp}$ & 198 & $18.2^{r}$ & $179.8^{\mathrm{i}}$ & $199.7^{\text {bc }}$ & $3.9^{\mathrm{b}}$ & 4.1 \\
\hline
\end{tabular}

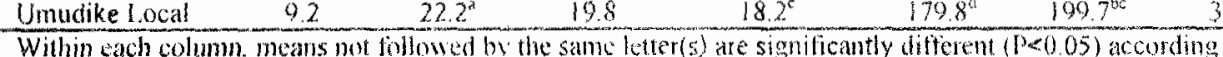

to Duncan's New Multiple Range Test

Tabie 4:Cane yield number of millable stalks and brix \% in six sugar cane genotypes

\begin{tabular}{|c|c|c|c|c|c|c|}
\hline \multirow[b]{2}{*}{ Variety } & \multicolumn{2}{|c|}{$\begin{array}{c}\text { Cane yield } \\
\text { (t/ha) }\end{array}$} & \multicolumn{2}{|c|}{$\begin{array}{c}\text { Number of millable } \\
\text { stalks } / \mathrm{m}^{2}\end{array}$} & \multicolumn{2}{|c|}{ Brix \% } \\
\hline & Ratoon & $\begin{array}{l}\text { Plant- } \\
\text { cane }\end{array}$ & $\begin{array}{l}\text { Plant- } \\
\text { cane }\end{array}$ & Ratoon & Plant-cane & Ratoon \\
\hline$\widehat{\mathrm{NCSO} 001}$ & $56.9^{3}$ & $13.9^{6}$ & 9.3 & $3.2^{b}$ & $25.7^{\text {a1 }}$ & 18.3 \\
\hline NCS 003 & $69.5^{\text {म }}$ & $38.6^{a}$ & 10.1 & $8.2^{a}$ & $22.7^{11}$ & $13: 3$ \\
\hline NCS 004 & $38.2^{\text {its }}$ & $17.6^{b}$ & 10.2 & $4.7^{\mathrm{b}}$ & $23.3^{b}$ & 14.7 \\
\hline NCS 005 & $71.0^{\circ}$ & $20.6^{b}$ & 8.3 & $4.4^{b}$ & $22.7^{b}$ & 13.0 \\
\hline$C 062175$ & $21.2^{b}$ & $37.9^{i l}$ & 3.8 & $8.1^{\mathrm{a}}$ & $21.7^{b}$ & 15.7 \\
\hline Umudike Local & $53.2^{a}$ & $22.9^{\mathrm{b}}$ & 9.5 & $5.4^{a b}$ & $28.3^{a}$ & 15.3 \\
\hline
\end{tabular}

Within each column, means not followed by the same letter(s) are significantly different $(P<0.05)$ according to Duncan's Multiple Range J'est. 
et al., (1965) and Ibrahim (1984) had attributed yield reductions in sugarcane to fewer number of millable stalks. The number of internodes/stalk was negatively but not significantly correlated with cane yield in both the plant-cane and ratoon crops. Umudike Local had the greatest number of green leaves in the ratoon crop but this did not proportionately reflect in cane yield. On the basis of consistency of yields obtained in both plant-cane and ratoon crops, the NCS 003 genotype was the highest while NCS 004 had the least under Umudike conditions.

Table 5: Correlations between plant attributes and canc yield in the plant cane and ratoon crops (1999-2001)

\begin{tabular}{|c|c|c|}
\hline \multirow[t]{2}{*}{ Attribute } & \multicolumn{2}{|c|}{ Cane yieid } \\
\hline & Plant-cane & Ratoon \\
\hline Number of green leaves/stalk & 0.291 & 0.345 \\
\hline Number of internodes/stalk & -0.151 & -0.085 \\
\hline Number of millable stalks $/ \mathrm{m}^{2}$ & 0.652 & $0.963 * *$ \\
\hline Stalk girth & 0.279 & 0.023 \\
\hline Stalk length & $0.811 *$ & 0.350 \\
\hline Brix content & 0.197 & -0.400 \\
\hline
\end{tabular}

* Significant at $5 \%$ probability level.

** Significant at $1 \%$ probability level.

\section{REFERENCES}

Agboire. S. and Ishaq. M. N. (1999). Development of improved sugarcane varieties through hybridization and selection. In National Cereals Research hastitute Anmul Reseanch Review Meeting Report Nationally Coordinated Research Programme on Sugarcane held at Badeggi. 20-23 April. 1999

Alexander, A. G. (1987). Evaluating varieties on sugar and biomass co-production systems Inter-American Sugar cane seminars; Miami, 23-25 September, 1987. In Genetic and harvest age influences on ethanolic fermentation from sugar cane juice. Edited by A. D. Celestine-Myrtil-Marlin. Sugary AZUCar, September 1991. pp 37-41.

3oerma, H. R. (1979). Comparison of past and recently developed soybean cultivars in maturing groups. Crop Science. 19(5): 611-613.

Brandes, E. W. (1956). Proc. Int. Soc. Sugarcane Tech., $9^{\text {th }}$ Cong. 731. In: Onwueme, 1. C. and Sinha. T. D. (1991). Field crop production in Tropical Africa CTA. Ede, The Netherlands. Pp 402-414.

Busari, L. D.; Misari, S. M.; Olaniyan, G. O. and Ndarubu. A. A. (1997). Weed management systems in chewing cane production in the inland valleys of Nigeria. Paper presented at the $16^{\text {th }}$ Biennial Conference of the Weed Science Society of Eastern Africa, held at Kampala Interuational Conference Centre. Uganda on 15-18 September, 1997

Cerrizuela, E.: Mariotti and Arevalo, R. A. (1965). Influ-
Ences of weeds on the growth of sugar cane. (In Spanish). Rev. Ind. Agric: Tucuman, 43:1-12.

Glaz, B.; Ullloa, M. F. and Parrado, R. (1989). Cultivation, cultivar and crop age effects on sugar cane. Agronomy Journal. 81(2): 163-167.

Ibrahim. A. A. S. (1984). Weed competition and control in sugar cane (Saccharum officinarium). Weed Res. 24:227-232.

Ishaq, N. M.; Echekwu, C. A.; Olorunju, P. E.; Gupta, U. S. and Misari, S. M. (1998). Variability and correlation studies in sugar cane. Agriculture Tropica et subtropica, 31:45-52.

Kwon-Ndung, E. H. (1998). Resistance of sugar cane clones, derived mutants and seedling progenies to smut disease (Ustilago scitaminea Syd.). Ph.D. thesis, Department of Botany, University of Jos, Nigeria.

Little, T. M. and Hills. F. G. (1978). Agricultural Experimentation Design and Analysis. John Wiley. New York. U. S. A. pp 87-100.

Ndarubu, A. A.; Busari, L. D. and Kolo, I. N. (1998). The effect of planting pattern and spacing on industrial and chewing sugar cane varieties. Paper presented at the $32^{\text {nd }}$ Annual Conference of the Agricultural Society of Nigeria, held at Federal College of Agriculture. Ishiagu, Ebonyi State. 14-16 September. 1998.

Okpara. D. A. and Ibiam, B. (2000). Evaluation of soybean varieties for adaptability to a humid tropical enviromment in south eastern Nigeria. Journal of Sustainable Agriculture \& Environment: 2 (1): 26-31.

Onwueme, 1. C. and Sinha, T. D. (1991). Field crop production in Tropical Africa. CTA. Ede. The Netherlands. pp 402-414.

Rehm. S. and Espig, G. (1991). The cultivated plants of the tropics and subtropics: cultivation. economic value. sutilization. CTA. Ede, The Netherlands. Pp 69.

Tanimu, B.: Ado. S. G.; Ibrahim. A. and Mani, H. (2001). Agronomic performance of local bambara groundnut (Vigna substerranea L. verdcourt) cultivars in northern guinea savanna zone of Nigeria. Journal of Agriculture and Environment. 2(1): 27-35.

Ugbaja, R. A. E; Adewole, T. A. and Omaliko, C. P. E. (1994). Genetic variability within accessions of castor oil plant (Ricinus communis). Journal of Science, Engineering and Technology. 1:23-29. 